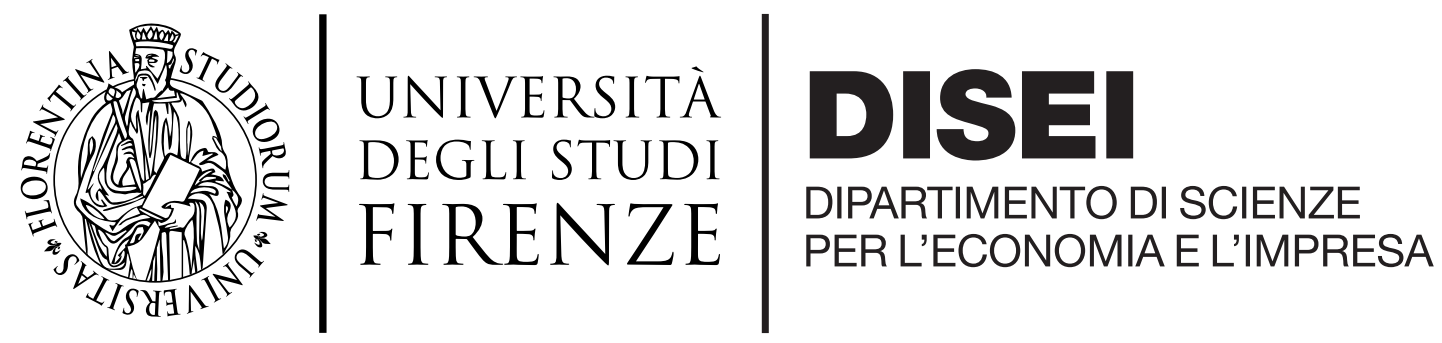

WORKING PAPERS - ECONOMICS

\title{
The Human-Centred Business Model and Hybrid Business Forms: A Primer and a Roadmap
}

\author{
Diletta LenZi AND ANDREA ZorZi
}

Working PAPER N. 13/2019 


\title{
The Human-Centred Business Model and Hybrid Business Forms: A Primer and a Roadmap
}

\author{
Diletta Lenzi \\ Post-doctoral research fellow \\ University of Trento, Faculty of Law \\ Andrea Zorzi \\ Aggregate professor of Business Law \\ University of Florence, Department of Economics and Management \\ Via delle Pandette 32, 50127 Firenze, Italy \\ e-mail zorzi.a@gmail.com
}

April 2nd, 2019

\begin{abstract}
The paper was written as part of the preliminary research for the Human Centred Business Model Project, a project developed within the Global Forum on Law, Justice and Development and now supported by the OECD Development Centre. In a preliminary fashion, the paper skims the surface of 'social' businesses, in the broadest sense, around the world, identifying some general trends and commonalities and some differences. The paper covers jurisdictions from North and South America, Europe, Asia and Australia and describes the organisations that can be used to carry out social business.
\end{abstract}

Keywords: corporate governance, corporate social responsibility, stakeholder value, social enterprise, benefit corporation, hybrid organizations

JEL codes: G30, G34, G38, K2O, K22, K38, L31, M14 


\section{Introduction*}

Less than a decade ago, Mohammed Yunus could write that the law offered no specific instrument to entrepreneurs that wanted to do business with a goal to make society better off. Writing at a very general and international level, he noticed that one had to adapt business forms to the 'social' aspect of business, observing that the law could hinder some important features of social businesses, such as the non-distribution constraint, and some forms of participatory governance. ${ }^{1}$

This is certainly not the case any longer. Since the last century, it is possible to observe a common trend towards a more sustainable way of doing business. ${ }^{2} \mathrm{~A}$ global cultural shift has occurred about the role of businesses and corporations in society, as well as about their 'responsibility' in terms of social and environmental impact: several initiatives have been developed on the international stage, ${ }^{3}$ and states are strongly

* The present research has been developed as part of preparatory activities for the HumanCentred Business Model Project, a research project developed within the framework of the Global Forum on Law Justice and Development - World Bank Legal Vice Presidency. The authors have been involved with the project since its inception and work mainly within the second of the six 'pillars' composing the project, focusing on the legal framework and corporate governance devices for a 'human-centred' enterprise. This pillar is co-lead by the International Institute for the Unification of Private Law (UNIDROIT) and the University of Florence (Università degli Studi di Firenze). Frédérique Mestre (UNIDROIT Senior Legal Officer) has been of precious help in the development of the research, with continuous comments and suggestions. The inventory of the existing initiatives and organisational forms has widely benefited from the collaboration with researchers at UNIDROIT between October 2017 and July 2018, coordinated by Frédérique Mestre who have helped in reporting from different jurisdictions. Namely, Lindsey Callahan (USA), Master of Laws (LLM) in Sustainable International Development Law at the University of Washington; Murat Cengizlier (Turkey), Master of Laws (LLM) in Sustainable International Development Law at the University of Washington; Li Jiankun (P.R. China), PhD Cand. of Private International Law, Wuhan University; Pedro Marcon (Brazil), Master in International Commercial Law, Università Europea di Roma/Universidade de Lisboa; Alessandra Pedinotti (France/Italy), Master/Laurea Mag. Cand. Univ. Poitiers/Roma 3; Irais Reyes de la Torre (Mexico), Master of Laws Rule of Law for Development, Loyola University Chicago School of Law (Rome); Tehilla Schwartz (Israel), LL.B. The Hebrew University of Jerusalem; Ashna Taneja (Australia), Master of Law (Global Competition and Consumer Law) Candidate, University of Melbourne; David Wouters (Belgium), Master in Laws, KU Leuven/LUISS (Rome). A previous version of this paper was presented at the 'Workshop on the Guiding Principles and Corporate Governance Research Papers', hosted by Unidroit, Rome, 12-13 November 2018.

The authors wish to thank Professor Francesco Vella (University of Bologna) for his useful comments and suggestions. Usual disclaimers apply.

${ }^{1}$ Yunus (2010).

${ }^{2}$ A preliminary study carried out by Unidroit in 2010 was able to list various old and new forms that could be apt to engage in social enterprises (Unidroit, 2010), but if that study were carried out now, the list would be significantly longer.

3 See, for instance, the United Nations, Guiding Principles on Business and Human Rights (2011), which is the first international set of guidelines for states and companies to prevent, address and remedy human-rights abuses committed in business operations; the UN Global Compact, Guide to corporate sustainability. Shaping a sustainable future (2014), which is directly addressed to businesses and lays out five defining features of corporate sustainability to 
encouraging and incentivising businesses to take into account environmental and social interests in their operations. For-profit entrepreneurs are also voluntarily moving beyond the 'mere' compliance with human rights provisions and environmental regulations, making real business out of sustainability. Perhaps it is still a matter of auspices, but there is a growing belief that we are going towards an economy in which economic growth and environmental responsibility work together in a mutually reinforcing fashion while supporting progress on social development'. ${ }^{4} \mathrm{~A}$ similar trend goes together with a growing cultural awareness of consumers and investors on the need for sustainability of both production processes and products. 5

Today, the market is no longer a place for the sole for-profit business model. In every economy the share of some form of 'social' business is increasing, and law and practice are developing new organisational forms to better carry out business and social activity, often referred to as 'social businesses', since they aim at generating a positive impact on society in the broadest meaning. It should be noticed, for the sake of clarity, that, while there is a common understanding that 'social' business is a business done for a goal that transcends the financial interests of shareholders or members, the term has very

strive towards (principled business; strengthening society; leadership commitment; reporting progress; and local action); the UN 2030 Agenda for Sustainable Development, which is the result of the General Assembly Resolution adopted in New York, on 25 September, 2015. The Agenda is a plan of action for people, the planet and prosperity, whose main aims are the Sustainable Development Goals (SDGs) and the 69 targets announced in the Agenda. The 17 SDGs are the main outcome of the UN 2030 Agenda for Sustainable Development. They came into force on $1^{\text {st }}$ January 2016. Even though they are not legally binding, governments are expected to establish national frameworks for their achievement: 'Countries have the primary responsibility for follow-up and review of the progress made in implementing the Goals, which will require quality, accessible and timely data collection. Regional follow-up and review will be based on national-level analysis and contribute to follow-up and review at the global level'.

See also the OECD, Guidelines for Multinational Enterprises (fifth version - 2011), including recommendations for responsible business conduct that the adhering governments encourage their enterprises to observe wherever they operate. The first version was adopted in 1976. The actual version (2011) includes recommendations on disclosure, human rights, employment and industrial relations, environment, bribery, consumer interests, science and technology, competition and taxation.

Finally, see the Global Reporting Initiative (GRI) Standards, released on 19 October 2016, an international set of reporting standards, and provides a good example for the development of reporting mechanisms in the context of the research of the Human-Centred Business Model. This is a manual for the preparation of sustainability reports by organisations, and takes into account the different corporate size, sector or location.

4 Definition of the International Chamber of Commerce (ICC, 2012).

5 Kassoy et al. (2016). It is very significant what Larry Fink wrote in 2018, in his annual letter to the CEO's of companies in which BlackRock invests: 'To prosper over time, every company must not only deliver financial performance, but also show how it makes a positive contribution to society' (...) 'Companies must benefit all of their stakeholders, including shareholders, employees, customers, and the communities in which they operate.' Read about the BlackRock's approach to sustainability at https://www.blackrock.com/corporate/responsibility (last accessed April 2, 2019). 
different implications depending on jurisdictions. Very generally, in Europe the concept of 'social' business tends to include some forms of profit distribution constraint (the EU operative definition requires reinvestment of most of the profits), ${ }^{6}$ whereas in the US this is not the case. Among the most notable of the many initiatives intended to provide a legal form to 'social' business which have occurred in the recent past, the most renowned is the US 'benefit corporation', which has no distribution constraint and has gone beyond US borders. Many European states have also provided advanced legal forms for doing 'social' business beyond social enterprises and the distribution constraint that they usually imply.

\subsection{Main Purpose of the Research}

This paper aims to provide a general overview of relevant existing 'hybrid' organisational forms, designed to carry out business with a view to generating a positive impact on the civil society, the environment, or other stakeholders, without foregoing profit altogether. This paper has been developed as part of the preliminary activities of the 'Human-Centred Business Model' (HCBM) project, within the framework of the Global Forum on Law Justice and Development (World Bank LegalVice Presidency). The project aims at fostering a holistic model to facilitate the development of an entire business ecosystem for those who want to run a business generating a positive impact on society and the environment while being economically sustainable. In order to carry out this kind of business, 'hybrid' companies are perfectly appropriate, given that they allow carrying out businesses organised in a collective way that balance profit and non-profit goals. ${ }^{7}$

Activities that seek to generate a similar impact indeed can be carried out by different kinds of organisations, some of which carry out business, some of which do not. In a very simplified manner, organisations having some sort of 'social' goal can fall within one of the following categories:

(1) not-for-profit organisations (such as associations, foundations, or charities) that do not carry out any business, and mainly rely on donations or grants to pursue their goals, or that may carry out business in an accessory fashion, as a means to provide financing to the pursuit of the social goal;

\footnotetext{
6 See infra at Par. 3.2.

7 For further information on the Human-Centred Business Model, visit the website http://globalforumljd.com/new/communities-of-practice/human-centered-business-model (last accessed April 2, 2019).
} 
(2) not-for-profit organisations (in any form) that pursue social goals but carry out business as a chore means to pursue their goal (e.g., some types of social enterprises);

(3) for-profit businesses that pursue social goals and also profit (in a varying degree, the main common ground being that they do not pursue only profit maximisation), which can be divided into:

(3.1) businesses that can pursue goals other than profit maximisation; (3.2) businesses that must also pursue social goals.

Among these categories, the research focuses only on categories (2) and (3), while notfor-profit organisations, when they do not carry out any business or when the business is a mere accessory of their activity (category (1)), are not included.

For each category, various governance characteristics have been analysed in order to sketch the core structure of each model. The collection of information, as well as the selection of corporate governance issues to be analysed, has been realised in a functional way, in order to underline only those examples that can be used in the quest for HCBM corporate governance frameworks. The limited aim of this paper is to give an overview of some of the many hybrid business entities available across jurisdictions, which could serve the HCBM. Further developments of the project may enable to broaden both the scope and the depth of the analysis.

The analysis has involved several jurisdictions, in order to understand whether and how entrepreneurs can run a business balancing (at different degrees) profit goals with not-for-profit ones, and when a business model requires such a balance.

Some laws enable members of for-profit entities to pursue not-for-profit goals, but some others do not. Even if a total profit-maximisation rule is probably inexistent, also in jurisdictions where corporate law tends to be mandatory and profit maximisation is the norm, the degree at which profit maximisation can be dispensed with is another issue; e.g., while for companies under some US laws, which are traditionally of an enabling nature, shareholders could set out special rules in the certificate of incorporation referring to the social or environmental sustainability of the business at the expense of profit maximisation, it may not be the same in other jurisdictions, where some legal categories (normally companies) are legally allowed to pursue profit only. This was the case of Italy until 2016, where companies could provide for some limited deviation from profit maximisation but could not, e.g., ban profit distribution, not even through a charter amendment. ${ }^{8}$ The issue of whether or not the law allows for the

\footnotetext{
${ }^{8}$ However, see Stella Richter (2017). This is also one of the reasons why, in order to do business that aims to balance profit with social and environmental goals, new specific legal provisions on the Italian benefit corporation were deemed necessary (see Par. 3.3.3.).
} 
pursuit of not-for-profit goals alongside profit by using a traditionally profit-oriented organisational form may seem trivial to those accustomed to enabling laws (leaving aside 'branding' issues) but should not be undervalued, since in many jurisdictions this is not possible, if there is no specific provision in the law that allows it.

In contrast, some jurisdictions have special provisions for types of organisations that the parties are free to use or not. If they do, they must also pursue not-for-profit goals (as defined by the law). This includes, on the more 'profit' side of the spectrum, hybrid forms such as 'benefit corporations' or 'public benefit corporations', which can freely distribute profit, and - on the other side of the spectrum - forms such as $\mathrm{L}_{3} \mathrm{Cs}$, community interest companies (in the UK), some types of co-operatives (e.g. in Italy), ${ }^{9}$ which can distribute profits, albeit with various limitations, and some kinds of 'social enterprises' as so defined by some laws.

Within this framework, the research concerns only types of organisations as provided by the law, through which it is possible to set up 'sustainable' businesses having also social or environmental goals.

The findings are organised by countries.

\section{The United States ${ }^{10}$}

In the US, the notion 'social enterprise' generically includes organizations of several levels of sustainability and stakeholders' involvement, from pure for-profit companies with a commitment to corporate social responsibility to not-for-profit organizations carrying out business. Also, state company laws across the US traditionally allow shareholders to set out, in the certificate of incorporation, special rules which refer to social or environmental pursuits.

The US can be considered as one of the countries in which the cultural shift first occurred and where the debate about the role of business in society has begun, at least so intensely, and perhaps as a reaction to the shareholder value maximisation norm.

In the US there are two main models, the low-profit limited liability company (or L3C),

\footnotetext{
9 Traditionally, the cooperative model developed with a 'social' impact (e.g. they have been traditionally used to further the position of working classes). However, coops are not per se 'selfless' or altruistic, in the sense that their finality is to enable members to buy at a lower price than market price, or sell at a higher price, or work for better wages, achieve affordable housing, access to credit on more favourable terms than commercial banking would allow. Cooperatives offer a typically participatory model of governance (members are also those who use the services or goods provided by the cooperative) and also a democratic model (the default usually being one head, one vote). Some jurisdictions have regulated 'social' cooperatives, e.g. Italy, Law no. 381/1991, and France, Law no. 624/2001.

For a worldwide comparative analysis of cooperatives see Fici et al. (2013).

10 Paragraph 2 is based on the work of Lindsey Callahan and Murat Cengizlier.
} 
and the benefit corporation (and similar forms). ${ }^{11}$ These models have taken a different approach to balancing the trade-offs involved when businesses pursue both profits and social or environmental goals. Slight differences are also reflected in state legislations within the same benefit corporation model (corporate law in the US is a matter of state law), where benefit corporations are often named differently.

\subsection{The Low-Profit Limited Liability Company (L3C)}

The first low-profit limited liability company (so-called ' $\mathrm{L}_{3} \mathrm{C}$ ') legislation has been enacted in 2008 by the US State of Vermont, as an amendment to the general limited liability company (LLC) act, rather than as a separate act. ${ }^{12}$ Since then, other ten US jurisdictions have followed. ${ }^{13}$

The $\mathrm{L}_{3} \mathrm{C}$ is a legal form of 'hybrid' business entity, the first of its kind to be provided in the US to bridge the gap between non-profit and for-profit business. It is a limited liability company prioritising the social impact along with the business success; a 'forprofit with a non-profit soul', ${ }^{14}$ aiming at combining the structure of a limited liability company with a social purpose.

The $\mathrm{L}_{3} \mathrm{C}$ is required to be a 'mission-driven' company, and its management is required to give higher priority to the achieving of the social mission than on making profits. This is made clear, for instance, in the Vermont, Illinois and Wyoming regulations: '[n]o significant purpose of the company is the production of income or the appreciation of property'. ${ }^{15}$ However, it seems that some return to investors is allowed, and there is no express non-distribution constraint. ${ }^{16}$

The original idea behind this model was to design a limited liability company capable to attract sustainable investors, and especially the program-related investments (PRIs) of

\footnotetext{
${ }^{11}$ Some authors expressly include both $\mathrm{L}_{3} \mathrm{Cs}$ and benefit corporations in the category of 'social enterprises', see Murray (2016).

${ }_{12}$ See Vermont Statutes, Title 11, Chapter 25, Subchapter 11 (Low-profit Limited Liability Companies), §§ 4161-4163.

${ }_{13}$ Similarly to Vermont, the following States have authorised the $\mathrm{L}_{3} \mathrm{C}$ model by amending their general limited liability company act: Illinois (805 ILCS 180); Louisiana (HB1421 / Act 417); Maine (H-819); Michigan (Sec. 450.4101 et seq.); North Carolina (H769 / SB308); Rhode Island (H5279); Utah (Tit. 48, Ch. O2c); Wyoming (Tit. 17, Ch. 15). On the contrary, the following federal jurisdictions have adopted specific $\mathrm{L}_{3} \mathrm{C}$ legislations: The Oglala Sioux Tribe; The Crow Indian Nation of Montana; The Navajo Indian Nation. Also, Puerto Rico has adopted a L3C legislation (A-233-2015). Information from https://americansforcommunitydevelopment.org/laws/ (last accessed April 2, 2019).

${ }_{14}$ This is how L3Cs are defined by the Americans for Community Development: see https://americansforcommunitydevelopment.org/ (last accessed April 2, 2019).

15 Vt. Stat. Ann. Tit. 11 §3001(27)(B) (2011); 805 Ill. Comp. Stat. 180/1-5 (2011); Wyo. Stat. Ann. §17-15-102(a)(ix)(B).

16 The absence of a threshold to profit distribution has been considered as a reason of the limited use of the model: see Pearce II-Hopkins (2014).
} 
private foundations which, in accordance to the Tax Reform Act (1969), have to periodically allocate $5 \%$ of their incomes to non-profit activities. ${ }^{17}$

Today, the $\mathrm{L}_{3} \mathrm{C}$ Model has been overcome in terms of popularity by the benefit corporation model. ${ }^{18}$

\subsection{The BLab Certification}

Hybrid businesses incorporated in any US state, as well as in any other country, can participate in the B Lab certification process and receive B Lab's Benefit Corporation certification. B Lab is mentioned here under the 'US' heading because it was founded and is headquartered in the US and its lobbying has been a main driver for benefit corporation statutes, as clarified below.

B Lab is a non-profit organisation, founded in 2006, aiming to build a global community of certified benefit corporations ('B Corps'), with the mission to 'redefine success in business'. It is self-defined as 'a global movement of people using business as a force for good'. ${ }^{19}$

B Lab employs two methods for achieving its mission. Firstly, it certifies companies as 'Certified B Corporations'. To do so, B Lab developed the 'B Impact Assessment', ${ }^{20}$ a standard for measuring the business social and environmental impact, its public transparency, and its legal accountability. To become a B Corp, businesses need to obtain 80 points or above out of a score of 200.

Secondly, it drafted a Model legislation for the development of Benefit Corporations, which has been highly influential on all legislation adopted in the US - and which has especially inspired the Washington State Social Purpose Corporation (see Par. 2.3).

B Lab certification is available in any jurisdiction: businesses today can voluntarily apply for compliance with standards set by the $\mathrm{B} \mathrm{Lab},{ }^{21}$ and there is no requirement that the business is run with any specific entity type.

\subsection{Benefit Corporations and Similar Entities}

In 2010, Maryland adopted its benefit corporation legislation, the first of the US States.

17 For a comment on L3C see Pearce II-Hopkins (2014); see also Callison-Vestal (2010) and D.S. Kleinberge (2010).

18 Also Vermont has now a benefit corporation statute, as most of the states throughout the US (see $§ 2.3)$.

19 See the B Lab official website at www.bcorporation.eu (last accessed April 2, 2019).

${ }_{20}$ More information are available here, https://bimpactassessment.net/ (last accessed April 2, 2019).

${ }^{21}$ All the Regional Sites are available at the B Lab official website www.bcorporation.eu. 
It was based on the 'Model Benefit Corporation Legislation' (MBCL) ${ }^{22}$, mentioned above. ${ }^{23}$

Mainly, B Lab's model legislation requires companies to pursue or create 'a general public benefit' and encourages (but does not require) that companies pursue one or more additional 'specific public benefits'. However, many State regulations (e.g. Delaware) require benefit corporation's bylaws to include at least one specific public benefit. Benefit corporations are the most typical example of hybrid companies, because they can also pursue profit, and typically do.

The general public benefit is defined as '[a] material positive impact on society and the environment, taken as a whole, from the business and operations of a benefit corporation assessed taking into account the impacts of the benefit corporation as reported against a third-party standard.' (MBCL $\S 201)$.

Specific public benefits include '(1) providing low-income or underserved individuals or communities with beneficial products or services; (2) promoting economic opportunity [...] beyond the creation of jobs in the normal course of business'; (3) preserving the environment; '(4) improving human health', '(5) promoting the arts, sciences, or the advancement of knowledge', and (6) fostering financing of entities having the purpose to benefit society (MBCL § 102; see also MBCL § 201).

The MBCL requires benefit corporations to consider the impact of business on society and the environment 'as a whole'. In pursuing the best interests of the benefit corporation, the board of directors (or the individual director) must consider the impact of its actions not only on the shareholders of the benefit corporation, but also on a series of other stakeholder-related matters. ${ }^{24}$ The Model Legislation lists what should be taken into consideration by directors: '(ii) the employees and work force of the benefit corporation, its subsidiaries, and its suppliers; (iii) the interests of customers as beneficiaries of the general public benefit or a specific public benefit purpose of the benefit corporation; (iv) community and societal factors, including those of each community in which offices or facilities of the benefit corporation, its subsidiaries, or its suppliers are located; (v) the local and global environment; (vi) the short-term and long-term interests of the benefit corporation, including benefits that may accrue to the benefit corporation from its long-term plans and the possibility that these interests may

22 The full version of the model legislation is available at http://benefitcorp.net/sites/default/files/Model benefit corp legislation _4_17_17.pdf (last accessed April 2, 2019).

${ }_{23}$ See, e.g., Cummings (2012), Hacker (2016), Hemphill and Cullar (2014), Hiller (2013), and Loewenstein (2013).

24 For a first analysis on the fiduciary duties of directors of benefit corporations, see McDonnell (2014). 
be best served by the continued independence of the benefit corporation (...)' (MBCL $\S$ 301(a)(1)).

All these interests are supposed to be balanced without giving priority to a particular interest over the others, 'unless the benefit corporation has stated in its articles of incorporation its intention to give priority to certain interests or factors related to the accomplishment of its general public benefit purpose or of a specific public benefit purpose identified in its articles' (MBCL § 301 (a) (3)).

A similar provision enables (and requires) directors to mitigate the traditional 'shareholder value approach'. ${ }^{25}$ At the same time, § 301(c) expressly denies any enforceable duty of directors (or officers, see § 305) to non-shareholder constituents, unless the company bylaws provide that an identified stakeholder category can bring an enforcement proceeding for the breach of duty to pursue or create general or specific public benefit.

The MBCL provides indeed for a 'benefit enforcement proceeding', which can be commenced only by the benefit corporation itself, or derivatively (in accordance with ordinary rules on the point), by a person or group of persons that own a certain amount of shares of the corporation or of its controlling entity (the MBCL suggests 2 and $5 \%$ respectively) ( $\$ 305$ ). Previous versions of the model legislation also suggested the possibility that articles of incorporation or bylaws of the benefit corporation could entitle another person or group of persons, but this suggested rule was removed in the most recent MBCL. ${ }^{26}$

Such an enforcement proceeding, however, has the effect of excluding other actions: as Section 305(a) states, no one can bring an action or assert a claim against a benefit corporation's directors or officers, with respect to their failure to pursue or create general public benefit or a specific public benefit set forth in its articles of incorporation, except in a benefit enforcement proceeding. In similar fashion, a benefit corporation cannot be held liable for monetary damages due to any failure to pursue or create general public benefit or a specific public benefit.

Finally, benefit corporations are required to draft, file with the secretary of state, and make publicly available an annual benefit report, describing how they have pursued their stated goals, and measuring levels of success in generating public benefits. If a

25 This is confirmed by MBCL $\S 301$ (e): 'A director who makes a business judgment in good faith fulfils the duty under this section if the director: (1) is not interested in the subject of the business judgment; (2) is informed with respect to the subject of the business judgment to the extent the director reasonably believes to be appropriate under the circumstances; and (3) rationally believes that the business judgment is in the best interests of the benefit corporation.'

${ }^{26}$ See, e.g., § 305(c)(iv) of the MBCL, Version of April 4, 2016. 
benefit director is designated (the designation is optional), one of his duties is to prepare the annual compliance statement. The assessment must also refer to a thirdparty standard that is comprehensive, credible, and transparent, and which is developed independently from the benefit corporation (MBCL $\S 102(a)$ ). However, the company can perform the assessment without a third-party audit or certification (MBCL § 401(c)).

If a benefit director is appointed, she is not 'personally liable for an act or omission in the capacity of a benefit director unless the act or omission constitutes self-dealing, wilful misconduct, or a knowing violation of law' (§ $302(\mathrm{e})$ ).

Finally, any existing corporation can be converted into a benefit corporation. Nothing is said about the dissenting shareholders' rights, but since the conversion into a benefit corporation can be considered as a fundamental change to the company, it would be better if the shareholders' appraisal rights were regulated in the bylaws; and this is actually what has been done in many states (see e.g. Delaware Public Benefit Corporation).

As of March 2019, 34 states have passed slightly different legislations on benefit corporations, while 6 states are working on it. ${ }^{27}$ Also, the US model(s) of benefit corporations has influenced the Italian legislation on 'società benefit' (below at Par. $3 \cdot 3 \cdot 3)$.

Among the 34 US states regulating benefit corporations it is possible to identify some main differences. If one considers the MBCL (and the Maryland legislation) to lie at one side of the spectrum, we can place the Delaware 'public benefit corporation' (PBC) on the opposite side; while the Washington 'social purpose corporation' (SPC) is located somewhere in between the two. ${ }^{28}$

\footnotetext{
${ }_{27}$ Updated information is available at the following link: http://benefitcorp.net/policymakers/state-by-state-status.

${ }_{28}$ California law is also interesting since it offers two options for socially oriented corporate governance structures (i) benefit corporations, on one side; and (ii) social purpose corporations (formerly called 'flexible purpose corporations'), on the other. California's benefit corporation closely follows the Model Benefit Corporation Legislation, and will not be further analysed. On the contrary, California's social purpose corporation (CSPC) was created in 2014, through the amendment of the California Corporate Code, and indeed the CSPC uses the California corporate form at its foundation, albeit in a much more flexible structure (Cal. Corp. Code $\S$ 2602(b)(2)). What seems relevant in this context is that, prior to the 2014 amendments, directors of FPCs (the former version of the actual CSPC) were permitted to consider stakeholder interests, while CSPC directors can now pursue purposes beyond (and even in conflict with) the shareholder value maximisation (see Cal. Corp. Code § 3501(c)). See, Brakman Reiser (2012).
} 
The Washington social purpose corporation legislation (2012) ${ }^{29}$ was crafted to provide more flexibility to businesses as compared to the MBCL: the aim for the Washington State legislator was to enable good corporate behaviour, while avoiding legislating corporate behaviour. ${ }^{30}$ Similarly to the MBCL, the social purpose corporation must have a general social purpose and has the option to have one or more specific social purposes. However, social purpose corporations seem to have a great deal of latitude in defining and pursuing social goals. ${ }^{31}$

With regard to directors and officers and their fiduciary duties, social purpose corporation directors and officers are permitted, but not required, to 'consider and give weight to one or more of the social purposes of the corporation as the [director or officer] deems relevant' (Wash. Rev. Code $\S 23$ B.25-06o(2) and o70(2)). However, the articles of incorporation may optionally impose the consideration of one or more of a SPC's social purposes. Any actions (or failure to take action) by a director or officer that they reasonably believe is intended to promote one or more of the social purpose corporation's social purposes, is presumed 'to be in the best interests of the corporation' (Wash. Rev. Code § 23B.25-6(3) and 7(3)).

With regard to reporting duties, differently from the MBCL, the identification of a third-party standard is not required. ${ }^{32}$

Similarly, the Delaware public benefit corporation ${ }^{33}$ voluntarily differs from MBCL to provide a corporation with sustainable-oriented options while not exposing it to increased liability. This intent shows in the extremely broadly definition of "public

29 House Bill 2239 introduced Chapter 23B.25, entitled 'Social Purpose Corporations', and amended Chapter 23B.01 of the Revised Code of Washington (RCW).

30 Reed Wellman Lewis, (2012). On SPCs see Mirzanian (2015).

${ }^{31}$ Under the Wash. Rev. Code, the general social purpose is defined in the law as follows: 'Every corporation governed by this chapter must be organized to carry out its business purpose (...) in a manner intended to promote positive short-term or long-term effects of, or minimize adverse short-term or long-term effects of, the corporation's activities upon any or all of (1) the corporation's employees, suppliers, or customers; (2) the local, state, national, or world community; or (3) the environment' (§ 23B.25-3).

${ }^{32}$ The board of directors is required to provide an annual report to shareholders that includes discussion of the SPC's efforts to promote its social purposes. The report may identify and discuss objectives related to the SPC's social purposes, actions taken or planned towards the achievement of its social purposes, and it describes 'the financial, operating, or other measures used by the corporation (...) for evaluating its performance in achieving its social purpose or purposes' (Wash. Rev. Code $\S 23$ B.25-16(2)). Differently from the MBCL, where a separate report is required, in a SPC, information on the business' 'social'/'sustainable' impact can be included in the corporation's regular annual report. However, these information must be made available to the public for free on the SPC's website (Wash. Rev. Code § 23B.25-16(1)).

33 Delaware passed benefit corporation legislation in 2013.

On public benefit corporations see, e.g., Dorff (2017). 
benefit', 34 as well as in the great deal of latitude in balancing different interests given to the director. ${ }^{35}$ Thus, directors' liability is even more limited as compared to the MBCL, especially when considering Delaware's deferential common law business-judgment rule.

Furthermore, public benefit corporations are not required to assess performance against a third-party standard. Benefit reports - discussing the corporate efforts with regard to its social purposes - are only required to be submitted biennially, and there is no requirement to make the report publicly available (Del. Code Ann. tit. § 366).

\subsection{The Delaware Voluntary Sustainability Certification Law}

In order 'to support Delaware business entities in their global sustainability efforts', in 2018 Delaware (as the first state in the US) has adopted a legislation enacting the 'Delaware Certification of Adoption of Transparency and Sustainability Standards Act', which became effective on October 1, 2018 (House Bill 310) ${ }^{36}$.

The Act enables a Delaware entity to be certified as a 'reporting entity', allowing it to disclose commitment to sustainability and transparency.

The decision whether to seek certification is entirely voluntary, as well as the chosen 'standards', considered as 'the principles, guidelines or standards adopted by the Entity to assess and report the impacts of its activities on society and the environment, which principles, guidelines or standards shall be based on or derived from third-party criteria' (Del. Code tit. 6, § 5001E-14).

In order to obtain the certification, an entity 37 has to apply to the Secretary of State, and pay a fee set by the law. Also, if the entity is a corporation, a limited liability company or another registered organization, it must be and remain in good standing and file an annual renewal statement.

34 'Public benefit' is defined as: 'a positive effect (or reduction of negative effects) on [one] or more categories of persons, entities, communities or interests (other than stockholders in their capacities as stockholders) including, but not limited to, effects of an artistic, charitable, cultural, economic, educational, environmental, literary, medical, religious, scientific or technological nature' (Del. Code Ann. 8 § 362(b)).

35 The board of directors is required to manage the public benefit corporation: 'in a manner that balances the stockholders' pecuniary interests, the best interests of those materially affected by the corporation's conduct, and the public benefit or public benefits identified in its certificate of incorporation'; in balancing these interests, directors cannot be held liable and their fiduciary duties to stockholders and the corporation are satisfied as long as the 'director's decision is both informed and disinterested and not such that no person of ordinary, sound judgement would approve' (Del. Code Ann. tit. 8 § 365).

${ }^{36}$ See Zeberkiewicz (2019).

37 Under the Delaware Certification of Adoption of Transparency and Sustainability Standards Act, 'entity' includes Delaware corporations, partnerships, statutory trusts, as well as any kind of association, as long as it is governed by Delaware law (Del. Code tit. $6, \S 5001 \mathrm{E}(6)$ ). 
Being qualified as a reporting entity allows it to improve the business 'social' reputation on the market and to attract actors interested in social and transparent investments. However, the Act expressly specifies that reporting entities are not required to disclose any trade secrets or other competitively sensitive information nor privileged information (Del. Code tit. 6, § 5001E-11f).

Finally, as regards the entity's members rights, the Act does not seem to recognise any right to claim the entity's decision to qualify (or not) as a reporting entity, nor to develop any specific enforcement mechanisms for a reporting entity's failure to comply with the standards.

\section{The European Union Framework}

\subsection{Introduction: The EU Policy on Corporate Social Responsibility and Sustainable Development}

Among the many initiatives on social economy and sustainable ways of doing business engaged at the European Union level, $3^{8}$ a cornerstone is the European Union strategy on Corporate Social Responsibility (CSR): the Green Paper 'Promoting a European Framework for Corporate Social Responsibility' presented by the Commission in July 2001, aimed at launching a debate on the concept of corporate social responsibility and identifying how to build a partnership for the development of a European framework for the promotion of CSR. Ten years later, the Communication of the European Commission of 2011 provided a 'renewed EU strategy 2011-14 for Corporate Social Responsibility'. ${ }^{39}$ The Communication, besides offering an interesting overview of CSR approaches across the European Union, addresses the European institutions, member states, and social partners as well as business and consumer associations, individual enterprises and other concerned parties, encouraging the development and the implementation of a common strategy to promote CSR throughout Europe.

Of the same year is the Communication on the Social Business Initiative (SBI) (COM(2011) 682 final), which has laid the foundations for the EU policy on social

${ }^{8}$ The first European Commission communication on social economy and business is of 1989: European Commission, 'Communication on business in the social economy sector', SEC(89) 2187, 18.12.1989.

39 Communication from the European Commission to the European Parliament, the Council, the European Economic and Social Committee and the Committee of the Regions. 'A renewed EU strategy 2011-14 for Corporate Social Responsibility', COM(2011) 681 final. See also, the communication from the Commission to the European Parliament, the Council, the European Economic and Social Committee and the Committee of the Regions 'Next steps for a sustainable European future. European action for sustainability, Strasbourg, 22 November 2016, $\operatorname{COM}(2016) 739$ final. 
enterprises (see below Para 3.2).

Since then, the EU has adopted a sort of 'nudge theory' approach, developing sectorial soft- and hard-law instruments to incentivise and facilitate the development of social entrepreneurship. ${ }^{40}$

Among the many EU actions in this sector, two documents seem to be particularly relevant with regard to the preliminary overview this paper presents. Firstly, the Directive 2014/95/EU of the European Parliament and of the Council of October $22^{\text {nd }}$, 2014 amending Directive 2013/34/EU as regards disclosure of non-financial and diversity information by certain large undertakings and groups, which imposes the disclosure of non-financial information to both public-interest entities, and to those public-interest entities which are the parent undertakings of large groups, in each case having an average number of employees above 500, in the case of a group on a consolidated basis. The disclosed non-financial information will 'provide investors and other stakeholders with a more complete picture of their development, performance and position and of the impact of their activity'. Under the Directive, certain (large) companies are now required to consider the impact of their business activities on the civil society and to give a review of policies, principal risks and outcomes. Although such duty of disclosure only applies to companies and other entities of a certain minimum size, the Directive does not prevent member states from extending the scope of similar rules through domestic law as well as, or, in its absence, on a voluntary basis via a corporate bylaws provision.

Secondly, the Communication from the European Commission entitled 'Action Plan: Financing Sustainable Growth' (Brussels, 8.3.2018 COM(2018) 97 final) is relevant. The Action Plan on sustainable finance is part of broader efforts to connect finance with the specific needs of the European and global economy for the benefit of the environment and society. Specifically, the Action Plan aims to reorient capital flows towards sustainable investment in order to 'achieve sustainable and inclusive growth, manage financial risks stemming from climate change, resource depletion, environmental degradation and social issues, and foster transparency and longtermism in financial and economic activity'.

In the same direction, the recent EU Shareholders Rights Directive (SRD II, Directive (EU) 2017/828) - aiming at enhancing the business long-term view, which European

\footnotetext{
40 See also the Regulation (EU) No 1296/2013 of the European Parliament and of the Council of 11 December 2013 on a European Union Programme for Employment and Social Innovation ('EaSI') and amending Decision No 283/2010/EU establishing a European Progress Microfinance Facility for employment and social inclusion, L. 347/238, December $20^{\text {th }}, 2013$.
} 
institutions consider having positive effect on both the business wealth and civil society and other stakeholders ${ }^{41}$ requires institutional investors and asset managers to develop and publicly disclose an engagement policy that describes not only how they integrate shareholder engagement in their investment strategy, but also how they monitor investee companies on relevant matters including non-financial performance and risk, and social and environmental impact (see Article $3 g$ (1) (a)). The implications and effects of the expected engagement of institutional investors are subject to discussion, but there is a tendency to fit also this engagement in the non-financial perspective of corporate governance.

Finally, along these lines, the report of the European Political Strategy Centre entitled 'Sustainability Now! A European Vision for Sustainability' is worth mentioning. ${ }^{22}$ Issued in July 2016, the report focuses on the EU's internal dimension, in order to analyse the EU Global Strategy on sustainability that aims to integrate the UN Sustainable Development Goals into a coherent EU Foreign and Security Policy.

\subsection{The European Union Framework for Social Enterprises}

With the 2011 Communication on the Social Business Initiative (SBI) (COM(2011) 682 final), the European Commission launched the EU policy on social entrepreneurship.

A social enterprise is defined by the Communication as 'an operator in the social economy whose main objective is to have a social impact rather than make a profit for their owners or shareholders. It operates by providing goods and services for the market in an entrepreneurial and innovative fashion and uses its profits primarily to achieve social objectives. It is managed in an open and responsible manner and, in particular, involves employees, consumers and stakeholders affected by its commercial activities' (COM(2011) 682 final, p. 2).

The Communication clarifies what is to be considered as a social enterprise under the EU legal framework. It is necessary:

(i) that the social or societal objective of the common good is the reason for the commercial activity and it is often in the form of a high level of social innovation;

(ii) that the profits are mainly re-invested with a view to achieving this social objective;

${ }^{41}$ Directive (EU) 2017/828 of the European Parliament and of the Council of 17 May 2017 amending Directive 2007/36/EC as regards the encouragement of long-term shareholder engagement.

${ }_{42}$ The text of the report is available at the following link: http://ec.europa.eu/epsc/publications/strategic-notes/sustainability-now_en (last accessed April 2, 2019). 
(ii) that the method of organisation or ownership system reflect the mission, using democratic or participatory principles.

The Communication recognises social enterprises as an instrument to foster (social) innovation and set the stage for the development of "horizontal policies in the context of the social economy and targeted programmes to support social enterprises and social innovation'. In particular, the Commission proposed an action plan in general support of social innovation and to enable social enterprises to use their full potential, containing measures such as improving access to funding, increasing the visibility of social entrepreneurship, and improving the legal environment for social enterprises.

In April 2013, as a follow-up to the 2011 Communication on the Social Business Initiative, the European Commission launched a study on the state, size, and scope of social enterprises in Europe. A first, very interesting report gives an idea of the scale of the phenomenon and consists of a map of social enterprises and their eco-systems in 29 European countries. ${ }^{43}$ Specifically, the study analyses the scale and characteristics of social enterprise activity in each country; the national policy and legal framework for social enterprise; the support measures targeting social enterprise; labelling and certification schemes where these exist; and social (impact) investment markets.

The study shows that, despite their differences, there are many common traits across Europe. Social enterprises mainly operate in three areas, namely:

(i) work integration: the training and integration of people with disabilities and unemployed people;

(ii) personal social services: health, well-being and medical care, professional training, education, health services, childcare services, services for elderly people, or aid for disadvantaged people;

(iii) local development of disadvantaged areas: social enterprises in remote rural areas, neighbourhood development/rehabilitation schemes in urban areas,

43 European Commission, 'A map of social enterprises and their eco-systems in Europe', Dec. 2014. The research is based on a review of national policy documents, academic and grey literature on social enterprise, but also on semi-structured interviews with a range of stakeholders such as social enterprises, policy makers, social enterprise networks, support providers, investors and intermediaries.

A second report has been published in January 2017, illustrating the state and development of social enterprise in Europe. See, European Commission, Social Enterprises and their Ecosystems: Developments in Europe, 2016, available at https://publications.europa.eu/en/publication-detail/-/publication/o1ob88f1-e6b9-11e6-ad7co1aa75ed71a1/language-en (last accessed April 2, 2019). The report is completed by seven country reports providing an overview of the social enterprises eco-systems in France, Italy, Spain, Belgium, Ireland, Slovakia and Poland (all available at https://ec.europa.eu/social/keyDocuments.jsp?advSearchKey=socenteco\&mode=advancedSub mit\&langId=en\&search. $\mathrm{x}=0$ \&search. $\mathrm{y}=0$ ). 
development aid and development cooperation with third countries. 44

Other fields include recycling, environmental protection, sports, the arts, culture or historical preservation, science, research and innovation, consumer protection, and amateur sports. 45

Within the Social Business Initiative framework, the European Commission stressed three areas of priorities: increasing private and public funding for social enterprises, improving their visibility, and developing a positive legal environmental.

Finally, after a Recommendation of the European Parliament, the European Commission is now working for the development of a 'European social economy label' for enterprises based on the social economy and solidarity. ${ }^{46}$ The label - meant to be valid in all Member States - would be available on an optional basis for businesses meeting the following requirements:

- being a private entity (independent of the State and public authorities) established within a EU member state;

- pursuing a general interest or public utility;

- being subject to an at least partial constraint on profit distribution and to specific rules on the allocation of profits and assets during its entire life (in any case, the majority of the profits made by the undertaking should be reinvested or otherwise used to achieve its social purpose);

- adopting democratic governance models involving employees, customers and stakeholders affected by its activities.

According to the proposal, the EU Commission should also establish a mechanism of certification and monitoring of the legal label, so as to increase the business's 'social' reputation on the market and facilitating access to finance.

The organisation willing to maintain the label would be also required to issue an annual 'social' report.

Notwithstanding the Recommendation of the European Parliament to the European Commission on a common statute for social and solidarity-based enterprises, the existing differences across member states keep open the debate on whether it is appropriate or necessary at the present moment to set up a specific legal form of social enterprise at the EU level.

44 See Dima (2018), 242-244.

45 See the European Commission webpage, specifically dedicated to Social Enterprises: http://ec.europa.eu/growth/sectors/social-economy/enterprises_en (last accessed April 2, 2019).

46 European Parliament resolution of 5 July 2018 with recommendations to the Commission on the Statute for social and solidarity-based enterprises, 2016/2237(INL). 
Nevertheless, the growing scale of social enterprises and hybrid companies across EU member states is clear: the number of social enterprises in the European Union is estimated to be currently between 130,000 and 250,000 , and it seems to be constantly rising; the social and solidarity-based economy in 2015 provided employment to more than 14 million citizens, consisting of around 6.5\% of workers in the European Union. 47

\subsection{Relevant Examples of Hybrid Companies in EU Member States}

After the overview presented in the previous paragraphs on the present framework at the European Union level, $4^{8}$ the following paragraphs will focus only on selected EU Member States, and specific innovative experiences, which have been considered particularly interesting for the development of the Human-Centred Business Model project. 49

\subsubsection{Belgium: The Experience of the Société à Finalité Sociale}

Belgium has been one of the first European countries to introduce a legal framework

\footnotetext{
47 Information gathered from the European Parliament resolutions of 19 February 2009, 20 $\begin{array}{lllll}\text { November } & 2012, & 10 & \text { September } & 2015 ;\end{array}$ https://oeil.secure.europarl.europa.eu/oeil/popups/summary.do? $i d=1544915 \& t=d \& l=e n \quad$ (last accessed April 2, 2019). See also Elodie Thirion (2017).

${ }^{48}$ Specifically on different legal forms of social enterprises across European States see Fici (2016).

49 Spain, for example, has not been analysed since Spanish social entrepreneurship is not as developed as that in other EU jurisdictions; see Mas-Machuca et al. (2017). See also the updated country report of the European Commission: European Commission, Directorate-General for Employment, Social Affairs and Inclusion (2016): Mapping study on Social Enterprise Ecosystems - Updated Country report on Spain, 2016, available at https://ec.europa.eu/social/BlobServlet?docId=16383\&langId=en (last accessed April 2, 2019).

The German legal framework is also not as developed in terms of hybrid model of doing business, despite its preeminent role within the EU economy and its long-lasting tradition of codetermination (the involvement of employees and labour representatives in the board). The mechanism is regulated by the 'Mitbestimmunggesetz' of May $4^{\text {th }}, 1976$, which applies to any company with more than 2000 employees (whereas the 'Montan-Mitbestimmunggesetz' of May $21^{\text {st }}, 1951$ regulates carbon-iron-steel industries; and 'Drittelbeteiligungsgesetz' of May $18^{\text {th }}$, 2004 regulates companies with less than 500 employees). Apply the 'operational' EU definition of social enterprise introduced by the Social Business Initiative (Par. 3.2.), no specific legislation on social enterprise seems to exist in Germany; 'neither does any legal delimitation of the phenomenon, and public agencies still diverge in their understanding of the concept. At this stage, the involved ministries do not seem bothered by the absence of an ultimate or official definition of the term', as reported by Göler von Ravensburg et al. (2018). The report gives also a brief overview of eight types of organisations that may be considered as social enterprises in the German context. There are two examples that can be mentioned in this context: (i) enterprises for the inclusion of persons with disabilities, which include both 'Werkstatt für behinderte Menschen' and 'Inklusionsunternehmen'; and (ii) enterprises for the integration of lowqualified youth, long-term unemployed and persons with labour market disadvantages other than a legally recognised handicap. These are both work integration social enterprises, which cannot however be defined as 'type' of business organizations (again Göler von Ravensburg et al., 2018).
} 
for organisations ascribable to the EU Commission definition of 'social enterprises': the société à finalité sociale (or 'SFS'), a social purpose company introduced in 1995 and regulated by Articles 661-669 of the original version of the Belgium Company Code, now in the process of being superseded.

The société à finalité sociale allows commercial companies to pursue goals other than profit. To be defined as an SFS, a company must pursue exclusively a 'social goal', while profit-making goals in favour of its members are not allowed. The members 'may obtain a limited profit from the assets of the company (determined by reference to a specific official rate) or no profit at all from the assets. Profits and reserves must be allocated in accordance with the social goal of the company, just like net assets in the case of the winding up of the company (with the exception of the refunding to members of the amount contributed by them to the capital)'. ${ }^{\circ}$ And indeed a not-for-profit association can legally convert itself into a société à finalité sociale without affecting its legal personality.

Also, employees have the option of becoming members. Furthermore, reporting systems are legally required: directors and managers have to draw up an annual report on the manner in which the company has taken steps to realise the social goal.

However, on February $28^{\text {th }}$, 2019, the Belgian Parliament adopted the new Company Code, which will enter into force on May $1^{\text {st }}, 2019.5^{51}$

The New Code on Companies and Associations will apply, as the name itself suggests, to both companies and associations. However, the distinctive criteria between companies and associations or non-profit organizations will be simplified: the main criterion of distinction will be the intention to distribute profits. On the contrary, the 'civil' or 'commercial' nature will be irrelevant, with the consequence that business activities could be organised through a non-profit organization as long as no direct or indirect dividends are distributed.

Under the new Code, only cooperatives will be able to qualify as social enterprises. According to Section 8(5), to be certified as a 'enterprise social' a cooperative must (i) set its main purpose as a purpose to act in the general interest, to generate a positive societal impact for the people, the environment or society; (ii) not distribute any profits to its members. The members can only take back their initial and effective contribution from the company, but dividend distribution during the life of the company, or at the

\footnotetext{
50 Unidroit (2010), 17.

${ }^{51}$ The new Code will apply to all entities incorporated after May 1st, 2019. For existing legal entities, as of January $1^{\text {st }}$, 2020, every modification of the bylaws will have to comply with the Code. After January $1^{\text {st }}, 2024$, any existing entity will have to be compliant with the new Code.
} 
moment of its liquidation, is be forbidden. Social enterprises in other forms will have to convert to cooperatives by 2024 in order to keep their status (Art. 42(1) of the Act).

\subsubsection{France: Towards a Political Engagement with a More Sustainable Way of Doing Business}

In France, an interministerial task force has recently published a Report entitled 'L'entreprise, objet d'intérêt collectif' (March $\left.9^{\text {th }}, 2018\right) .5^{2}$

The Report aims at allowing companies to assign a broader, more varied object to their businesses.

The Report develops several policy recommendations. Recommendation No. 1 is particularly interesting. It suggests modifying the French Civil Code to include, in the definition of a company's essential components (namely, a lawful object and a grounding in a common shareholder interest), a rule providing that corporations should be managed in their own interest, but considering the social and environmental aspects of their activities. A similar expression seems to recall the one of Section 172 of the UK Companies Act (see Par. 4).53

Recommendation No. 2 recommends requiring the board of directors to consider social and environmental aspects of the company's activities, notably by using the company's 'fundamental purpose' as a strategic guide to business.

Recommendation No. 11, in order to give a legal grounding to mission-based undertakings, proposes to enable companies to state a fundamental purpose ('raison d'être') in their bylaws.

Recommendation No. 12, finally, gives statutory recognition to a mission-based undertaking, which should be available to companies of any legal form, provided that they meet four conditions:

(i) a fundamental purpose is stated in their articles of constitution;

(ii) an 'impact committee' exists, comprising, where necessary, stakeholders;

(iii) there is third-party monitoring and the company reports publicly on its compliance with its stated fundamental purpose;

(iv) and, for companies with over 500 employees, publication of a declaration on non-financial performance (this provision is in line with the EU Directive on nonfinancial statements - see Par. 3.1).

\footnotetext{
$5^{2}$ Senard and Notat (2018).

53 Recommendation No. 1 seems to have been acknowledged in Draft Law June 19, 2018 No. 1088 aiming at amending Article 1833 of the Civil Code and Articles L. 225-35 and L. 255-62. Information gathered from Tombari (2019) at p. 46-47.
} 
The Report seems in line with the 2014 Law for a social and responsible economy (Law No. 2014-856, 31 July 2014), which introduced and regulates two 'labels': the 'Entreprise de l'économie sociale et solidaire' (ESS) and the 'Entreprise solidaire d'utilité sociale' (ESUS). Businesses can be qualified as ESS companies if they (Article 1):

- pursue a social purpose of common utility ('utilité sociale') as defined by the law (Article 2);

- manage the business in a democratic way;

- do not distribute any profit.

Businesses can also obtain the ESUS label if they (Article 11):

- pursue a social purpose of common utility ('utilité sociale');

- set a cap on the compensation of directors and of some employees;

- demonstrate that the social business has an impact on the expenses of the company (as determined by the Conseil d'Etat, Decree 15 June 2015, No. 0145)

To be defined as an ESUS company the law does not seem to require limitations on profit distributions.

\subsubsection{The Italian Experience of 'Società Benefit' and the Recent Reform of Social Enterprises}

Italy was the first European country to adopt a legal regime for the 'società benefit', a hybrid company inspired by the US benefit corporation experience (Par. 2), and is thus probably the most advanced legal framework in Europe in this respect. 54

As in many continental European jurisdictions, until 2016 Italian companies could be only used to pursue for-profit goals (according to Article 2247 of the Italian Civil Code), which is why, in order to do business that aims to balance profit and social/environmental goals, a new specific legal provision introducing the Italian società benefit was necessary.

The società benefit is conceived as a for-profit company, which aims at generating a 'general public benefit', intended as a material positive impact on the civil society and the environment, as measured by a third-party standard, through activities that promote a combination of specific public benefits. The general and vague definition of 'public benefit' recalls the Delaware Public Benefit Corporation more than the US

54 The società benefit is regulated by the 'Stability Act' of 2016, Act No. 208/2015, Article 1, paragraphs $376-382$. 
MBCL, while the third-party standard seems inspired by the latter (see Par. 2.3). 55

The 'public benefit' has to be defined in the certificate of incorporation and directors must consequently balance the profit goal with the pursuit of the general public benefit and can be considered as potentially liable in the case of an erroneous balancing. However, the regulation on società benefit is complemented with ordinary legal provisions on corporate governance structure and enforcement mechanisms for director's misconduct: such rules have been created in a profit-centric way, and do not consider the specificities of a hybrid organisation. E.g., to consider a director liable for misconduct, damages to the common assets are required, but it is difficult to imagine how a balance that prefers the profit to the social goals will generate a detriment to the corporate assets.

Consistently with the US experience, the Italian benefit corporation does not provide any stakeholders' involvement within the corporate governance. Any business organisation type under the Italian Civil Code can be converted into a benefit corporation, including cooperatives and partnerships.

In spite of the absence of any tax benefits approximately 187 società benefit were incorporated as of June 2018.56

The Italian legal framework is particularly interesting also in light of a recent reform of social enterprises ('imprese sociali').

A social enterprise model exists in Italy since 2006 (Act No. 155/2006), when the law provided a legal status that could be obtained by any non-profit organisation pursuing social aims. 57

Legislative Decree n. 112 of July $3^{\text {rd }}, 2017$ repealed the previous legislation on social enterprises and newly regulated the model, as part of the 'third sector' organizations (Article 19). To be defined as such, a social enterprise, today, has two main options:

(i) it must carry out - as its primary business - one of the activities of 'public/general interest' as listed and narrowly defined in Article 2 (there are more than 22 activities, mainly in the areas of education, welfare and health). ${ }^{8}$ However, under the reformed

55 On società benefit, see Denozza-Stabilini (2017), Corso (2016), Lenzi (2016), and StellaRichter (2017).

${ }^{6}$ Assonime (2016).

${ }^{57}$ For an overview of the phenomenon of social enterprises in Italy see the Country Report of the European Commission. European Commission, Social enterprises and their eco-systems: A European mapping report. Updated country report: Italy, $2^{\text {nd }}$ Ed., 2016, available at http://ec.europa.eu/social/keyDocuments.jsp?advSearchKey=socentcntryrepts\&mode=advance dSubmit\&langId

${ }^{8}$ Activities listed in Article 2 are considered having per se a 'social' impact on the communty and no other investigations are required. This is not the case in other jurisdictions, where 
legal framework, social enterprises can exercise these 'social' activity also together with other commercial activities, as long as $70 \%$ or more of the total profits come from the main, social business activity;

(ii) or, it can exercise any business as long as the way in which business is carried out has a 'social impact', i.e. hiring of at least $30 \%$ of disadvantaged workers (disabled people, former inmates, people with drug addictions, etc.). In this case, the social enterprise can exercise any business activity and it is not limited to the ones listed in Article 2, as in the first case.

As under the previous regulation, Legislative Decree No. 112/2017 does not create a new legal entity. Rather, almost any kind of entity can be organized as a social enterprise (Article 1): associations, foundations and non-profit organizations on one side; and companies (with the only exceptions of single-member companies; Article 1(2)) or cooperatives, 59 on the other side.

The most relevant characteristics of the new Italian social enterprise can be summarised as follows. ${ }^{60}$ Firstly, the social enterprises articles of association or incorporation should provide for procedures for stakeholder consultation (the focus is mainly on employees). Stakeholders (and employees above all) should be enabled to exercise a certain influence on the management (Articles 10 and 11). However, in spite of the fact that stakeholder involvement is required, directors seem to remain subject to the same traditional fiduciary duties, which are owed to members of the organisation only; and no form of stakeholder enforcement is provided.

Secondly, under certain conditions SEs can distribute profit up to a certain threshold (less than $50 \%$ of the profits; Article 3). This can be probably considered as the main innovative aspects of the Italian reform, and as a unique example among EU member states: within the European context, social enterprises were indeed traditionally characterised by the impossibility to distribute any profit. ${ }^{61}$ On the contrary, today, social enterprises not only can generate profits, but they can also distribute them to its members (directly or indirectly) with the limit of less than $50 \%$ of profits.

Also, social enterprises must draw up a non-financial annual report, to be published on the national business register and on the SE's website (Article 9, para. 2).

Furthermore, tax benefits are provided: profits are tax exempt if they are reinvested

businesses have to pass a test verifying the generated benefit for the community; i.e. the Community Interest Companies in the UK (see infra Par. 4).

59 Social cooperatives (regulated by Law 381 of November $8^{\text {th }}, 1991$ ) are automatically qualified as social enterprises (Article 1, para. 4).

${ }^{60}$ For a holistic analysis of the new impresa sociale, see the papers collected in the special issue of Analisi Giuridica dell'Economia, Volume No. 1/2018.

${ }^{61}$ Fici (2016). 
into the social enterprise and not distributed to its members; below certain thresholds and under certain conditions (among which that the investment must be made for at least three years), money invested in an SEs is tax deductible for the investor. ${ }^{62}$

Finally, within the reform, social enterprises are able to raise financing through crowdfunding portals.

Together with the social enterprises reform, the Italian legislator also published a 'code' for the third sector (Legislative Decree n. 117 of July $3^{\text {rd }}$,2017) uniformly regulating associations and foundations. The 'code' allows these organizations to run businesses not only in a collateral way but also as the main activity as long as: (i) they do not distribute any profit (Articles 11(2) and 13(4)); and (ii) they carry out a (business) activity of 'general interest' (in compliance with Articles 5 and 6).

\section{The United Kingdom: The Community Interest Company (and Section 172 of the Companies Act)}

Similarly to the US, the UK legal framework is mainly of an enabling nature. Businesses pursuing social goals, and whose surpluses are partially reinvested for that purpose, can be carried out by corporations, partnerships, charities, cooperatives, and 'community interest companies'. ${ }^{63}$

The community interest company (CIC) consists in a legal model of 'social enterprise', meant as a business with primarily social objectives, which has been introduced by the Companies (Audit, Investigations and Community Enterprise) Act of 2004. Community interest companies aim to meet the economic needs of producing goods and services with the primary purpose of improving the benefits for civil society and the social community in which they operate and/or of their stakeholders. The regulation is the result of the work of the Social Enterprise Unit established in 2002 within the then Department of Trade and Industry. The programme was meant to develop a legal environment enabling entrepreneurs to do business in a sustainable way.

Community interest companies are regulated by the Community Interest Company Regulations of 2005, as amended in 2009, but they also have to respect the general rules of company law, as regulated by the UK Companies Act of 2006.

To be defined as such, a Community Interest Company should respect the following requirements:

(i) 'passing' the community interest test, that is that a 'reasonable' person should

${ }^{62}$ Article 18 as modified by Legislative Decree No. 95/2018

63 On community interest companies see Cabrelli (2016), and Copp (2009). 
judge the community interest company's business as generating a benefit for the community (Section 35(2) of the 2004 Companies Act);

(ii) corporate profits should be mostly (a) retained within the company to fund its activities, and (b) used to benefit the community. ${ }^{64}$ Community interest companies can also carry out collateral normal business activities, but dividends to investors can only be paid up to a certain amount;

(iii) be certified as such by an independent Regulator of Community Interest Companies, who is also in charge of supervising the future activity of the community interest company. 65

Any company may elect to become a community interest company (see Companies Act 2004, Section 26(1) and (2) of the 2004).

Several provisions aim at ensuring that assets and profits are not diverted from the intended community goals, through an asset lock ${ }^{66}$ and a dividend cap. In 2014 the dividend cap was simplified and is now calculated only on profits, so that at least $65 \%$ of the profits should be reinvested within the company. A cap is also established for the debt holders and the payment of their interest rate (so-called 'interest cap', see Community Interest Company Regulations of 2005, Annex No. 4) As the Regulator notes, '[t]he dividend cap strikes a balance between encouraging people to invest in CICs and the principle that the assets and profits of a CIC should be devoted to the benefit of the community. This helps to ensure that the dividends are not disproportionate to the amount invested and the profits made by the company'. ${ }^{67}$ The same balance is sought, as recalled earlier, by the Italian law on 'social enterprises', which was amended in 2017: the prior total non-distribution constraint (of 2006) was scaled down to a limit of 'less than 50\%' profits that can be distributed.

The UK legal framework deserves attention in this context also with regard to Section 172 of the UK's Companies Act 2006, entitled 'Duty to promote the success of the company', which requires a director of any company to 'act in a way he considers, in good faith, would be most likely to promote the success of the company for the benefit

\footnotetext{
${ }^{64}$ See the definition of community at Section 35(5) of the 2004 Companies Act.

${ }^{65}$ See Regulator of Community Interest Companies, Annual report 2016-2017. The report gives an overview of community interest companies in the UK; it is available at the following link: https://www.gov.uk/government/publications/cic-regulator-annual-report-2016-to-2017.

${ }^{66}$ E.g. see Section 1 of Annexes No. 1, 2 and 3 of Community Interest Company Regulations of 2005 , in relation to the possibility to transfer business' assets.

${ }^{67}$ Office of the Regulator of Community Interest Companies: Information and guidance notes.

Chapter 6: The Asset Lock, May 2016, Ch 6.3, available at https://www.gov.uk/government/publications/community-interest-companies-how-to-form-acic
} 
of its members as a whole'. Therefore, in theory, in doing so, directors should take into consideration the interests of stakeholders other than shareholders, such as the one listed in the Section: employees, suppliers, consumers, community and the environment. Further, they should consider 'the desirability of the company maintaining a reputation for high standards of business conduct' and 'the need to act fairly as between members of the company'. The Section is meant to promote the socalled 'enlightened shareholder value' principle. ${ }^{68}$

Section 172 has been heavily criticised as being nothing more than a 'codification of directors' duties'. It should also be noted that no specific enforcement mechanisms have been provided, while a common remark is that putting the interests of different stakeholders (e.g. employees and the environment) at the same level could actually generate conflicts of interest. ${ }^{69}$ 'Thus' - it has been very well said - 'the exhortation to boards to pursue their corporations' interests is less an equal sharing norm than, at best, a vague counsel of virtue, and, at worst, a smokescreen for board pursuit of their own interests'. ${ }^{70}$

\section{Latin America: A Brief Overview on the B Corp Movement ${ }^{71}$}

South America is subject to a wave of innovations in terms of social entrepreneurships; the BLab movement is extremely active and is able to operate across jurisdictions in a more co-ordinated way than in other countries. The movement aims at becoming an effective framework for entrepreneurs, and self-qualifies as a network that offers solutions to businesses willing to operate in a sustainable way. ${ }^{72}$ As a matter of fact, it is being quite successful in pressing for the adoption of ad hoc legal frameworks at the country level, promoting the introduction of 'Sociedades B.I.C.', a legal organisation inspired by the US MBCL and Italian società benefit experiences (see Par. 2.3 and 3.3.3) as well as the UK Community Interest Company (see Par. 4).

In Argentina, a draft law proposed by the Executive Power in 2016 and approved by the lower chamber at the end of 2018 provides for a business model similar to that of benefit corporations, in which directors have to consider the effects of their business on

${ }^{68}$ See Keay (2013). For a critique to a similar theory see, e.g., Davies and Gower (2012).

69 Tsagas (2017).

70 Enriques et al. (2017).

${ }^{71}$ Paragraph 5 has benefited from the work of Irais Reyes de la Torre.

72 See the official webpage of the $B$ Corp movement in Latin America at https://sistemab.org/en/empresas-b-america-latina/ (last accessed April 2, 2019). 
civil society and on the environment in which they operate. ${ }^{73}$ The proposed law is, however, very detailed comparing to the US MBCL or the Italian società benefit, since it specifically regulates important corporate governance aspects such as enforcement mechanisms, members' appraisal rights, and thresholds for profit distribution. It also requires companies to develop an annual report describing the actions carried out to comply with the self-imposed social and/or environmental goals, which would be audited by an independent registered professional specialised in the subject. At this stage, the draft law does not seek to introduce a new corporate type; and it does not provide any tax exemption or fiscal benefit.

A new regulation, similar to the Argentinian one, has been proposed in Brazil as well. It appears that the Brazilian Group of experts in B Corp has finalised the third version of the draft law. The most suitable draft is the one which considers benefit corporations not as a new type of corporation, but as a legal qualification for the existing types of companies, conditional to changes in the corporate bylaws to indicate the purpose of social and environmental impact on the corporate purpose, adapt the governance of the company to assess decision-making in relation to stakeholders, the community and the environment, through the creation of an impact director and/or a multidisciplinary impact committee, and provide for the publication of an annual impact report (the same as is provided by the Italian law on società benefit).

In June 2017, a draft bill was presented in parliament aiming at regulating the creation and operation of 'beneficial companies' and 'collective interest companies'. This project does not regulate the management of the assets of the company nor the distribution of its profits, but only the enforceability of compliance with the purpose adopted in the corporate bylaws and the report that the companies must perform annually.

Finally, a similar movement is also active in Peru and in Uruguay (proposed legislation by members of the house of representatives of Uruguay dates September $\left.15^{\text {th }}, 2017\right) .74$ The second country outside the United States after Italy to regulate benefit corporations, Colombia has recently passed the law introducing the Sociedades Comerciales de Beneficio e Interés Colectivo (BIC) (Law June 8, 2018, No. 1901).

Similarly to the US and to Italy, BIC companies are not a new type of organization. To become a BIC, a company is required to modify its articles of incorporation (with standard majorities for charted amendments) including in them the pursue of a public

73 See http://sistemab.org/wp-content/uploads/2017/04/Proyecto-Ley-BIC.pdf (last accessed April 2, 2019).

${ }^{74}$ For a comparative overview of social enterprises and hybrid organizations in Latin America, see Silva (2018). 
benefit, which is not specifically defined in the law. This gives great flexibility to the model, as occurs with benefit corporations. Directors must balance the corporate interest (identified with the one of its members) and the public benefit as defined in the bylaws (Article 4). However, comparing to the models it is inspired by, the Colombian BIC seems to specifically focus on employment rights (salaries, training, relocation, etc.) (Article 2).

The Colombian law as well requires BICs to publish a report on the improvements in the pursuing of the public benefit (Article 5). In a way similar to that of the Italian Law on società benefit, the report should be consistent with independent standards (Article 6).

\section{Asia: An Overview 75}

\subsection{Introduction}

China, Japan and South Korea are marked by a co-operative and associative tradition, which have remained for a long time under the strict control of the administrative and political power. Only recently this public interventionism has faded in Japan and South Korea, and has diminished in China, with the consequence that autonomous cooperatives and associations have been able to emerge and develop, as progressively recognised by law.

However, South Korea is, for what it is concerned, the only Asian country which provides an ad hoc legal framework for social enterprises, which is progressively inspiring other Asian countries.

In South Asia economy is less developed and it is still predominantly rural. Here, local and international NGOs provide an essential contribution, organising activities that seek to provide an answer to poverty and exclusion. Taking as an example the Philippines (on which see Par. 6.4), Cambodia and Indonesia, two relevant organisational forms exist in all three jurisdictions:

(a) non-profit co-operatives, meant as collective self-employment responses to unmet needs, based upon the co-operative tradition, mainly developed as agricultural cooperatives (but also as social co-operatives, especially in Indonesia); and

(b) Community Development Enterprises, intended as multi-stakeholders partnerships (e.g. non-profit organizations) promoting participatory local development.

75 Paragraphs 6.1., 6.2., and 6.3. are based on the work of Alessandra Pedinotti; while Paragraph 6.3 is based on the work of Li Jiankun. 
Beyond their differences (mainly due to different historical roots), the identified Asian countries seem however to share four economical and sociological features, whose relative impact varies according to the national contexts: ${ }^{76}$

(i) the growing role of not-for-profit organisations in providing social services (privatisation);

(ii) the consequent trend of not-for-profit organisations to adopt a marketoriented approach and to participate in public procurement tenders;

(iii) the growth of the corporate social responsibility movement across the continent;

(iv) and a growing awareness of the positive effects of a more sustainable way of doing business among both civil society and the academic world.

\subsection{A Legal Framework for Social Enterprises: The Case of South Korea}

With the 2007 Social Enterprise Promotion Act (SEPA), South Korea became the first Asian country to enact a specific legal framework to support social enterprises. As stated in Article 1, the purpose of this regulation was to contribute to social integration and the improvement of the citizens' quality of life by expanding social services and creating new jobs through support for the establishment and operation of social enterprises and their promotion. 77

The Act is part of the Korean Labour Laws and the Minister of Employment and Labour is responsible for implementing a plan for the promotion of social enterprises every five years after the deliberation of the Employment Policy Council. Social enterprises have been indeed introduced with the primary aim of providing new job opportunities, but also as an attempt to establish a more formalised civic society, ${ }^{78}$ by employing disadvantaged people (at least 50\% of the total employees), providing for social services to disadvantaged groups (at least $50 \%$ of the total users of the service) and, more generally, by generating a positive impact on the local community.

Legal entities that can be certified as social enterprises are: (i) non-profit organisations carrying out business; (ii) associations regulated by civil law; and (iii) corporations as regulated by the Commercial Act. In 2014, social enterprises were mainly organised through companies (50.7\% of the total), followed by organisations under the NonProfit Organisations Act (21.7\%), Associations under Civil Law (18.8\%), Foundations

\footnotetext{
76 Defourny and Kim (2011).

77 Bertotti et al. (2014).

78 Defourny and Kim (2011).
} 
under Social Welfare and Services Act (5.8\%), Co-operatives under Farmers and Consumer Co-operative Act (2.2\%). 79

To be certified by the Minister of Employment and Labour as social enterprise, the following requirements must be satisfied (Articles 7 and 8):

(i) Social goals: the main purpose of the enterprise must be to realise a social objective (e.g. improving the local residents' quality of life; providing vulnerable groups with social services or jobs; contributing to local communities), as defined by an ad hoc Presidential Decree.

(ii) Stakeholders' participation: a social enterprise must have a decision-making structure in which interested parties, such as service beneficiaries and workers, can participate. The law does not, however, specify which mechanisms should be used to ensure such participatory governance and the stakeholders' involvement in general.

(iii) Profits: revenues from business activities of social enterprises must not exceed certain limits defined by the law. Specifically, Article 3 states: 'A social enterprise shall make efforts to reinvest the profits generated through its business activities into the maintenance and expansion of the social enterprise' (Section 3); 'No associated enterprise shall gain the profits generated by a social enterprise' (Section 4).

(iv) Dividends: if the social enterprise is organised as a company under Commercial Law, whenever it has distributable profits, it must spend at least the two-thirds of the profits of each fiscal year on social objectives (Article 8).

An organisation that meets the requirements listed above can be qualified as a social enterprise under South Korean law. No legal person other than social enterprises can use the name of social enterprise or any other similar names (Article 19).

The benefits offered to companies fulfilling these conditions are varied: they include a favourable tax regime, subsidised jobs, exemptions from social security contributions, the possibility of borrowing at a favourable rate and easier access to public markets (Article 12). The Minister of Employment and Labour also supports social enterprises with professional consultation on management techniques (Article 10 and Article 10-2), taxation (Article 13), labour affairs (Article 14), accounting and others. State or local autonomous governments can further support social enterprises, by the lease of stateowned or public land (Article 11), and by reducing the fiscal pressure or providing tax exemptions (Article 13 again). ${ }^{80}$

79 Bertotti et al. (2014).

80 In 2010, in addition to the amendments of the SEPA, two important events stressed the interest of public policies towards social enterprises.

The first one concerns the involvement of new ministries, namely, the Ministry of the Interior or the Ministry of Agriculture. The social enterprise certification scheme, which since 
The South Korea legislation on social enterprises has inspired Thailand that in 2010 has adopted the Thai Social Enterprise Office (TSEO), which has been established under the Thai Health Promotion Foundation Act, as the executive authority to deliver the Social Enterprises Master Plan (2010-14). The Office's priority is to stimulate cooperation among social enterprises and develop their networks in Thailand.

With the only exemption of South Korea and Thailand, however, other Asian countries do not have regulated the phenomenon, nor they have converged to a common definition of 'social enterprise', 'social entrepreneurship' and 'community business', but there still seems to be as many definitions as there are Asian countries. However, in spite of the absence of a common legal framework for social enterprises, the Asian Institute for Social Entrepreneurship (ISEA) was created in 2001 to set up a learning and action network to catalyse knowledge creation, capacity development and movement-building for social entrepreneurship in Asia.

\subsection{China: The Farmers' Specialised Cooperatives and the Social Welfare Enterprises}

Unlike South Korea, China does not have a structured legal framework for social enterprises. Due to the similarities of the Chinese translation of 'social enterprises' and 'corporate social responsibility', the two concepts have often been considered to be synonymous. ${ }^{81}$

Among the different Chinese organisational models, there are mainly two examples that seem to be somewhat characterised by a balance between profitability and social sustainability: (i) Farmers' Specialised Cooperatives; and (ii) Social Welfare Enterprises.

In general, China has a massive cooperative sector (around 160 million families involved), ${ }^{82}$ especially focused on agriculture, and even private co-operatives operate under the strict control of public authorities.

2007 has been controlled by the Ministry of Employment and Labour, in 2010, was partially extended to other ministries through interministerial contracts awarded under the programme of 'pre-social enterprise job creation'. These contracts follow under the specific competences of each Ministry, e.g., the Ministry of Education encourages initiatives in the field of school support. This has extended the reach of the social enterprises' impact to sectors of the economy other than the labour market (e.g. education).

The second trend is the growing involvement of local communities through different support initiatives for social enterprises. In the context of the 2010 regional elections, many local authorities have also adopted measures that have led to the definition of regional-type social enterprises (e.g., the Seoul social enterprise), inspired by the SEPA model. This involvement of the regional authorities is also financially supported by the decentralisation of certain budgets.

${ }^{81}$ Defourny and Kim (2011). See also Wang and Zhu (2010); and Man and Terence (2013).

82 Defourny and Kim (2011). 
Within the existing cooperatives types, the farmers' specialised cooperative (FSC) seems to be the closest Chinese example of hybrid companies.

The farmers' specialised cooperative is a mutual-aid economic organisation, which is voluntarily adopted for the production and management of agricultural products (the purchase of agricultural production materials, sale, processing, transport and storage of agricultural products, as well as the technologies and information relating to agricultural production and business operations), in favour of its members.

A farmers' specialised cooperative must observe the following principles:

(i) at least $80 \%$ of its members must be farmers. Also, if the members are less than 20 , only one of them can be an enterprise, a public institution or a social organisation. If the number of members exceeds 20, $5 \%$ of them may be enterprises, public institutions and social organisations;

(ii) it must aim to provide services to its members and seek the common interests of all its members;

(iii) it must ensure the equal treatment of its members and the free withdrawal from membership;

(iv) it must be managed in a democratic way;

(v) the surplus is to be returned to the members according to the volume (amount) of transactions with the farmers' professional co-operative.

According to the law, a farmers' specialised cooperative can invest in enterprises and other companies, and take limited responsibility for the enterprises invested in, although it cannot be listed on the capital market.

Being an farmers' specialised cooperative can be rewarding in terms of dedicated legal benefits, such as fiscal support, preferential tax treatment, and other financial and capacity building support.

Enacted in 2006, farmers' specialised cooperatives have then grown rapidly, and, by June 2010, the number of officially registered FSCs had exceeded 300,000, while 25 million farmer households (which consist of $10 \%$ of China's total farm households) have become members of farmers' specialised cooperatives.

Another interesting example in China can be found in Social Welfare Enterprises, businesses set up for the employment of people with physical or mental disabilities (at least the majority of the employees), Even if, since the 1990s, those models have started to decrease rapidly, mainly because of the China's market-oriented operational model, 
in 2008 there were still 23,000 social welfare enterprises across China, employing nearly 620,000 people with disabilities. ${ }^{83}$

Finally, in 2016 the B Corp movement has reached China: since then, ten companies have been certified as B Corps. ${ }^{84}$

\subsection{Malaysia and the Philippines}

Despite the absence of a specific legal setting for social enterprises, more and more entrepreneurs in Malaysia are defining their business as 'social'. Social businesses are carried out through existing legal entities, from associations to limited liability companies. However, a common definition of social enterprise does not exist yet, and entrepreneurs rely on components of the social enterprise that they consider important to qualify as such. Generically, they are understood to be entities that accomplish a social mission using an economic model, like a combination of elements of both NGOs and for-profit enterprises, and Malaysian social enterprises are strongly influenced by the British Model of the Community Interest Company (see Par. 4 above).

As in Malaysia, no legal framework for social enterprises exists in the Philippines.

However, the cultural environment in the Philippines has been sensitive to social entrepreneurship since the last century. In 1999, the Philippine Social Enterprise Network (PhilSEN) ${ }^{85}$ was created to discuss the practices and experiences of social enterprises, operating mainly as a capacity-building supporter for social entrepreneurs. Two bills that could have a direct impact on social enterprises have been under discussion in recent years: the Social Value Bill and the Poverty Reduction through Social Entrepreneurship ('PRESENT') Act. However, these bills still do not seem to have been passed. PhilSEN is currently lobbying for the PRESENT Bill in both the Senate and Congress in order to promote social enterprises 'as vehicles for poverty reduction and spearheading social enterprise education in the country'.

\section{Australia: the Indigenous Corporation and the Developing Framework for Benefit Corporations ${ }^{86}$}

Australian company law does not permit for-profit companies to pursue social goals at the expense of making profit: to do so may be a breach of the directors' fiduciary duties (firstly, the duty to act in good faith in the best interests of the company). The current

\footnotetext{
83 Defourny and Kim (2011).

84 Updated information at https://www.bcorpasia.org/china/ (last accessed April 2, 2019).

85 Information available at http://philsocialenterprisenetwork.com/.

86 Paragraph 7 is based on the work of Ashna Taneja.
} 
for-profit governance structures in Australia do not give enterprises enough flexibility to pursue their social goals in circumstances in which profit may be compromised. Organisations have to choose either to be a for-profit structure in order to access equity funding (without the tax and financial benefits of a not-for-profit structure or the access to grants and donations), or to be a not-for-profit structure in order to be eligible for donations and grants and gain tax concessions (but without the ability to raise equity funding or distribute profits to members).

Despite the absence of a separate legal framework for social enterprises, widespread consensus describes them as organisations with an economic, social, cultural or environmental mission that is consistent with a public or community benefit; and whose majority of profits or surpluses is re-invested into fulfilling their missions. ${ }^{87}$ Considering such 'operational' definition of 'social enterprise', there were approximately 20,000 social enterprises operating in Australia in 2016, with $38 \%$ in operation for more than 10 years, and 33\% of them in operation for a period between 2 and 5 years, with an annual turnover that varies from zero to AUD 199 million.

'Social enterprises' are mainly associations (32.8\%), followed by companies limited by guarantee (31.3\%), and private companies (18\%). $75 \%$ of them are small organisations, $23 \%$ are medium-sized organisations, and $3.6 \%$ are large organisations.

The large majority of 'social enterprises' re-invest all of their income into their business (81\%), while less than $15 \%$ re-invest half of their income into their business. This reflects a clear preference for not-for-profit legal structure. ${ }^{88}$

${ }^{87}$ See the research report produced in collaboration between the Centre for Social Impact, Swineburne University of Technology, and Social Traders entitled 'Finding Australia's Social Enterprise Sector 2016' (FASES), available at https://www.socialtraders.com.au/findingaustralias-social-enterprise-sector-2016-analysis/, which provides an overview of the activity of social enterprises in Australia.

88 The most common social goals pursued by Australian 'social enterprises' as of 2016 were income equality/poverty alleviation, creating meaningful employment opportunities for a specific group of individuals, or developing new solutions to social, cultural, economic or environmental problems.

The most common beneficiaries were the wider community or public (61\%), followed by the members (less than 25\%), and generally serving the beneficiaries of a related not-for-profit entity (less than 15\%). The largest beneficiaries of the work of social enterprises are people with disabilities (34.9\%), young people (33.3\%) and disadvantaged women (27.5\%). Other beneficiaries of social enterprise activity include people with alcohol, drug, or substance use issues, Aboriginal and Torres Strait Islanders, a particular geographic community, the elderly, families, the homeless, migrants, refugees, or asylum-seekers, LGBTI individuals, disadvantaged men, individuals with mental illness, prisoners and ex-offenders, remote or rural communities, the unemployed, animals, and the environment. Finally, $68 \%$ of social enterprises are providing services (rather than goods) for a fee.

All the data are gathered from the FASES Report (2016). 


\subsection{Indigenous Corporations}

An interesting and unique model, which may be of inspiration for the development of 'hybrid'/'sustainable' companies especially in developing countries and emerging markets, and for micro and small enterprises, is the Australian Indigenous Corporation.

Indigenous corporations are a type of limited liability company that is only available for Aboriginal and Torres Strait Islander (ATSI) organisations (which however are not limited to organise their business through this legal structure). The idea was to create a corporate structure that suits the specific needs of a marginalised community and accounts for its limitations. Indigenous Corporations, for instance, can take into account the Indigenous customs and traditions in their bylaws (referred to as the 'rule book'). Also, they are monitored by a specialist regulator, the 'Office of the Registrar of Indigenous Corporations' (ORIC), rather than the Australian Securities and Investments Commission (ASIC).

It is interesting to notice the central role played by the Office, oriented at simplifying creation and development of indigenous corporations, and make the whole process cheaper.

Firstly, ORIC has additional powers beyond pure regulation and it provides Indigenous Corporations with simplified and cheaper processes for registering. For example, ORIC provides a bylaws model that only needs to be filled in with the business personal information. Furthermore, no fees are charged for registering as indigenous corporation; and the reporting requirements to ORIC are generally low. Also, ORIC assists indigenous corporations through several services, from face-to-face training in remote areas, to dispute resolution services, telephone advice, assistance with examining books and records to identify financial, and corporate governance issues. ORIC also provides access to free legal advice through an in-house 'LawHelp' service. To incorporate as an indigenous corporation the following requirements must be met:

(i) at least 5 members must be ATSIs;

(ii) there must be no less than 3 and no more than 12 directors on the board; and

(iii) the majority of directors must be ATSIs.

Finally, even if indigenous corporations are, by default, for-profit entities, they can also register for non-profit status and operate accordingly. However, directors remain subject to the same fiduciary duties to their members only, like other public and private company directors. In this case, the members of an indigenous corporation are the desired beneficiaries underlying the social purpose, similarly to a co-operatives model. 


\subsection{Proposal for the Introduction of Benefit Corporations}

In 2016, the Australia and New Zealand branch of B Lab ${ }^{89}$ formed a working group composed by academics, lawyers, business leaders, and governance experts to draft amendments to the Corporations Act 2001 and to set up a regime for benefit corporations in Australia. On 27 February 2017, B Lab submitted a draft set of provisions and an accompanying explanatory memorandum to the Australian Department of Treasury as part of a submission on the subject of social impact investing.

The following are the main features of the proposed amendments, which are inspired by the US Model Benefit Corporation Legislation (see Par. 2).

A benefit company must have a purpose of creating a general public benefit in its constitution and may include a purpose of creating one or more specific public benefits (Section 190C). Section 125A(1) defines what a positive social impact is and requires at least one purpose of creating general public benefit. In doing so, the directors or other officers of a benefit company must consider (i) the likely consequences of any decision or act in the long term; (ii) the interests of the company's employees; (iii) the need to foster the company's business relationships with suppliers, customers and others; (iv) the impact of the company's operations on the community and the environment; $(v)$ the desirability of the company maintaining a reputation for high standards of business conduct; (vi) the interests of the members of the company; and (vii) the ability of the company to create the general public benefit it has elected to pursue and any specific public benefit purpose in its constitution. Directors need to consider all these matters equally, unless the benefit company has stated in its constitution that they must give priority to certain matters related to the accomplishment of the general public benefit purpose or any specific public benefit purpose in its constitution (Section 2.3).

Only a private company (limited by shares), a public company (limited by shares), or a public company (limited by guarantee) are eligible to be benefit corporations.

Finally, a benefit corporation in Australia could distribute profits to its members with no limitations.

\section{Israel ${ }^{90}$}

Notwithstanding the deficiency of a legal framework for 'hybrid' companies, it is possible to observe a growing interest for sustainable businesses in Israel, from the

\footnotetext{
${ }^{89}$ See the official website at https://bcorporation.com.au/about-b-lab/global-partners/ (last accessed April 2, 2019).

9o Paragraph 8 is based on the work of Tehilla Schwartz.
} 
abundance of facilitation in the form of social impact funds, accelerators ${ }^{91}$ and hubs, as well as the Forum for Social Enterprises in Israel, ${ }^{92}$ striving to aggregate the relevant information on social business in Israel, which, however, provides minimal, if any, legal guidance. 93

\subsection{Non-Profit Organizations and Public Benefit Companies}

There are mainly two legal forms that seem relevant to the HCBM framework, nonprofit organisations (NPOs) and public benefit companies (PBCs). In Israel, traditional companies (private limited liability companies) and partnerships must strive for profit maximisation, although they may pursue any other legal goal, consequently considering stakeholders' interests as part of its business considerations. Companies can also donate a reasonable amount of money to charities, for a 'worthy cause', outside business considerations, as long as this is somehow realised in the shareholders interest, as is common in most jurisdictions.

PBCs, despite having a name very similar to entities similar to benefit corporations that are found in some US jurisdictions (Delaware to begin with - see above, Par. 2.3), have very little in common with their American false friends. PBCs are the organisations mostly utilised by public and national institutions such as museums, schools, colleges, synagogues, research and policy-making institutes, etc.: PBCs pursue social goals only, and cannot distribute any profit. They are regulated by the Companies Law, No. 57601999, but they are also partially subordinated to the same regulator of non-profit organisations (the Registrar of Amutot). PBCs differ from non-profit organisations since (i) PBCs are companies by definition, while NPOs can choose to be organised as a company, but do not have to; and (ii) the social goals must be chosen from a predetermined (extremely broad) list provided by the legislator (see Schedule II of the Israeli Company Law). Under court permission, shareholders may transfer the ownership of their PBC participation.

Very much like non-profit organisations, PBCs must provide proper reporting on the promotion of social goals, in exchange for tax benefits.

NPOs (Regulated by the Amutot Law, n. 5740-1980) can exercise business activity as long as they remain not-for-profit. Coherently, profit distribution is prohibited and NPOs' memberships cannot be transferred or sold. 'Certificate of Proper

\footnotetext{
$91 \quad$ E.g. 'The 8200 Social Program'; which official website is https://www.thesocialprogram.co.il/ (last accessed April 2, 2019).

92 Information are available at the Forum official website: http://www.sef.org.il/ (last accessed April 2, 2019).

93 See Gidron (2010), and Feit (2011).
} 
Management'- issued by the Registrar of Amutot after an examination of compliance with the various NPO Law provisions - must be obtained in order to receive tax benefits. A key component to receiving the certification is a non-financial annual report detailing the actions taken to promote the NPO's objectives, the organisational structure, the corporations whose officeholders are also officeholders in the NPO, etc.

\subsection{Proposed Legislation on Social Enterprises}

Already in 2012, the Prime Minister's office held a roundtable discussion on the topic of social enterprises. The definition provided for the discussion was that of a business activity within a non-profit organization or a public benefit company, which strives mainly to achieve social goals alongside profit; or, alternatively, 'a company that aims to achieve social goals alongside profit maximization, and has included a profit distribution limitation for private investors up to $50 \%$ after the initial investment are returned'. 94

In 2017, a joint initiative of the Israel Venture Network - a venture philanthropy network that invests in social businesses - and various parliament members from different political parties, brought forth a legislation proposal (Legislation Proposal $4088 / 20 / \mathrm{P}$ ) to create a tailor-made legal structure for social enterprises, a process of approval which is still ongoing. The proposal is not to pass a new law altogether, but rather to amend the Companies Law and Partnership Ordinance so as to include specific provisions on social enterprises, forming a social enterprise company and/or a social enterprise partnership.

If the law passes, Israeli social enterprises will be required to identify social goals among those listed by law, excluding the mere activity of donation to other entities, within the company bylaws. Directors will have to, consequently, prioritise the social goal over profit maximisation. If the company wishes to change the goal, a $75 \%$ majority vote and the approval of the Registrar of Companies are required.

With regard to profit distribution, the company will be permitted to put a cap on profit/bonus distribution of shares, up to 50\%. This cap would only apply after the initial investment has been returned. Alternatively, changing the cap on profit

94 See the Recommendations of The Secondary Committee Of Social Enterprises Regarding the Definition of Disadvantaged Communities, Prime Minister's Office (27.2.2012); CEO instructions for social businesses assistance plan (pilot) 4.31, Ministry of Economy (first published 13.05.2014, last updated 19.09.2017); online version available at http://economy.gov.il/legislation/ceoinstructions/instructions/04_31_19_09_2017.pdf (last accessed April 2, 2019). 
distribution would be possible only with the 90\% majority and the approval of the Registrar, or with the permission of the court.

A social enterprise will then have to submit an annual 'social impact report' on the activity and progress it has made in pursuing the social goals, together with the financial report, both of which are to be made public.

Other customary rules are envisaged by the proposed legislation. A social enterprise will only be allowed to merge with another social enterprise and only with the approval of the Registrar. Also, the court will have the authority to order the liquidation of a social enterprise if it has engaged in illegal activities or it has acted contrary to the goals determined in the bylaws. The assets of a liquidated company are transferred to the shareholders of the company. However, if the company has established a distribution cap, the shareholders only receive assets up to the value of their initial investment, and the remaining assets are transferred to either a non-profit or a public benefit company that pursue similar social goals.

\section{Final Remarks: Why We Need the HCBM and What Works for It}

This preliminary paper attempts to skim the surface of 'social' businesses, in the broadest sense, around the world. It has no intention to be more that a list of examples and a work plan on the need to deepen and broaden the research, but some trends and needs can be identified in order to better focus on the possible role of the HCBM and on the issues it will face.

The inventory of the existing models of 'hybrid forms' of doing business in a more sustainable way, together with the growing European and international awareness testify how policy- and lawmakers around the globe are becoming more and more conscious of the impact of business on the environment and on civil society. Over the last decade, a cultural shift has started to take place in the debate about the role of business in society. As a result, many businesses have sought to operate in more socially responsible and sustainable ways, consumers have started to make purchasing decisions based upon good business practices, and governments have begun to enact laws that both enable and foster an environment in which businesses can play a more positive role in society.

As part of this effort, many legal systems have enacted legislation to create corporate governance structures that enable businesses to make decisions and carry out operations in more socially oriented ways. 
However, something is still missing. Firstly, there is a lack of common definitions: concepts such as 'social enterprise' or - to a lesser degree - 'benefit corporation' differ among jurisdictions, sometimes on very central aspects (such as profit distribution constraints).

Secondly, corporate governance mechanisms intended to ensure compliance of directors to the goals of the company are still mainly based on the common governance rules, traditionally based on profit-centric companies, and require further thought when goals are also social and environmental. Hybrid organisations introduce greater complexity into the corporate structure, while seeking to attain the benefits of for-profit and not-for-profit structures. A similar complexity cannot be faced in the traditional corporate governance structures developed in a 'profit-centric' perspective, but ad hoc mechanisms should be developed to protect minority shareholders from a change of purpose, provide effective directors' fiduciary duties, assure capital lock-in, protect stakeholders and intended beneficiaries, etc. On another note, hybrid companies increase the burden of reporting requirements, including non-financial reporting.

Thirdly, there is an extremely important issue of branding for hybrid organisations. Being recognisable in a complex and layered market is key to business, as well as social, success, and bringing different initiatives, across multiple countries, under the same roof may prove valuable for all actors involved. This is even more so for young businesses seeking to gain market access and build up a customer base: creating legitimacy around their business operations and goals is key to attracting and retaining customers

Moreover, a common 'brand' could assist social enterprises in communicating to potential investors and grantors or donors their social purposes, while adequate governance systems, tailored on the hybrid nature of the organisation, would help to ensure that commitment is credible. This would improve a social enterprise's ability to attract 'social' investors and secure access to finance or grants that have a social purpose requirement for eligibility.

Within this context, the Human-Centred Business Model Project acknowledges the existing initiatives, and aims to go beyond them, developing an alternative, sustainable, business ecosystem, which respects the profit motive, within a framework of social and environmental sustainability. This paper is a preliminary contribution to one of the aspects of this projected business ecosystem, touching upon issues of governance. 


\section{References}

Assonime, 2016, La disciplina delle società benefit, Circolare No. 19 (June 20 ${ }^{\text {th }}$ )

Bertotti et al., 2014, Governance in South Korean social enterprises: Are there alternative models?, Social Enterprise Journal, 10(1), 38-52

Brakman Reiser D., 2012, The Next Big Thing: Flexible Purpose Corporations, Am. U. Bus. L. Rev., 2, 55-83

Cabrelli D., 2016, Distinct 'Social Enterprise Law' in the UK? The Case of the 'CIC', University of Edinburgh School of Law Research Paper Series No 2016/27, 1-16

Callison J.W., and A. Vestal, 2010, The L3C Illusion: Why Low-Profit Limited Liability Companies Will Not Stimulate Socially Optimal Private Foundation Investment in Entrepreneurial Ventures, Drake University Legal Studies Research Paper Series, No. 11-07, 273-294

Copp S., 2009, Corporate Social Responsibility and the Companies Act 2006, Economic Affairs, 29 (4), 16-21

Corso S., 2016, Le società benefit nell'ordinamento italiano: una nuova "qualifica" tra profit e non-profit, Le nuovi leggi civili commentate, 5, 995-1031

Cummings B., 2012, Benefit corporations: How to Enforce a Mandate to Promote the Public Interest, Colum. L. Rev., 112, 578-627

Davies P.L., and L. Gower, 2012, Principles of Modern Company Law, Sweet \& Maxwell

Defourny J., and S.-Y. Kim, 2011, Emerging models of social enterprise in Eastern Asia: a cross- country analysis, Social Enterprise Journal, 7(1), 86-111

Denozza F., and A. Stabilini, 2017, La società benefit nell'era dell'investor capitalism, Orizzonti del Diritto Commerciale, V(2), 1-15

Dima A.M. (eds), 2018, Doing Business in Europe, Springer

Dorff M. B., 2017, Why Public Benefit Corporations? (October 5, 2016). Delaware Journal of Corporate Law (DJCL), 42, Forthcoming; Southwestern Law School Research Paper No. 2016-10. Available at SSRN: https://ssrn.com/abstract=2848617 (last accessed April 2, 2019)

Enriques L., H. Hansmann, R. Kraakman, and M. Pargendler, 2017, The Basic Governance Structure: Minority Shareholders and Non-Shareholder Constituencies, in R. Kraakman et al. (eds), The Anatomy of Corporate Law: A Comparative and Functional Approach, OUP

Feit G., 2011, Social Businesses in Social NGO's in Israel: Issues in Taxation and Incorporation, Maasei Mishpat, Tel Aviv University Journal of Law and Social Change, 185-203 (in Hebrew)

Fici A. et al., 2013, International Handbook of Cooperative Law, Springer 
Fici A., 2016, Recognition and Legal Forms of Social Enterprise in Europe: A Critical Analysis from a Comparative Law Perspective, European Business Law Review, 27(5), 639-667

Gidron B., 2010, Policy Challenges in Light of the Emerging Phenomenon of Social Businesses, Nonprofit Policy Forum., 1 (1), 2154-3348

Göler von Ravensburg N. et al., 2018, Social Enterprises and Their Ecosystems in Europe. Country Report: Germany

Hacker M.A., 2016, "Profit, People, Planet” Perverted: Holding Benefit Corporations Accountable to Intended Beneficiaries, B.C.L. Rev., 57, 1747-1780

Hemphill T. and F. Cullari, 2014, The Benefit Corporation, Business and Society Review, 119(4) 519-536

Hiller J., 2013, The Benefit Corporation and Corporate Social Responsibility, J. Bus. Ethics, 118, 287-301

ICC, 2012, Green Economy Roadmap. A guide for business, policy makers and society to drive sustainable growth in a resource-constrained world with strong demographic growth, available at https://iccwbo.org/publication/icc-green-economy-roadmap-aguide-for-business-policymakers-and-society-2012 (last accessed April 2, 2019)

Kassoy et al., 2016, Impact Governance and Management: Fulfilling the Promise of Capitalism to Achieve a Shared and Durable Prosperity, Brookings Institute Center for Effective Public Management, available at https://www.brookings.edu/research/impact-governance-and- management-fulfillingthe-promise-of-capitalism-to-achieve-a-shared-and-durable-prosperity/ (last accessed April 2, 2019)

Keay A.R., 2013, The enlightened shareholder value principle, Routledge

Kleinberge D.S., 2010, A Myth Deconstructed: The 'Emperor's New Clothes' on the Low Profit Limited Liability Company, Legal Studies Research Paper Series, Working Paper No. 2010-03

Lenzi D., 2016, Le società benefit, Giur. comm., I, 894-920

Light P. C., 2011, The Search for Social Entrepreneurship, Brookings Institution Pres

Loewenstein M.J., 2013, Benefit Corporations: A Challenge in Corporate Governance, Bus. Law., 68, 1007-1038

Man C.H, and Y.Y. Kai Terence, 2013, A General Overview on Theory and Practice of Chinese Social Enterprise, Journal of Ritsumeikan Social Sciences and Humanities, 5, $165-178$

Mas-Machuca M. et al., 2017, Unveiling the mission statements in social enterprises: a comparative content analysis of US- vs. Spanish-based organizations, Journal of Social Entrepreneurship, 8(2), 186-200

McDonnell B., 2014, Committing to doing good and doing well, Fordham Journal of 
Corporate \& Financial Law, 19-72

Mirzanian S., 2015, Washington's Social Purpose Corporation: Creating Accountability for Corporations or Simply Providing a Halo to Undeserving Corporations?, Seattle Journal of Environmental Law, 5 (1), 257-280

Murray J. H., 2016, The Social Enterprise Law Market, Maryland Law Review, 541-589

Pearce II J.A., and J.P. Hopkins, 2014, Regulation of L ${ }^{3}$ Cs for Social Entrepreneurship: A Prerequisite to Increased Utilization, Neb. L. Rev., 92, 259-288

Reed J., and A. Wellman Lewis, 2012, Washington State Adopts New Form of Corporation That Allows Companies to Combine Profitability with Broader Social Purpose, Davis Wright Tremaine LLP, available at: https://www.dwt.com/WashingtonState- Adopts-New-Form-of-Corporation-That-Allows-Companies-to-CombineProfitability-with-Broader-Social-Purpose-05-07-2012/ (last accessed April 2, 2019)

Senard J-D, and N. Notat, 2019, L'entreprise, objet d'intérêt collectif, available at https://www.ladocumentationfrancaise.fr/rapports-

publics/184000133/index.shtml\#book_sommaire (last accessed April 2, 2019)

Silva J.A., 2018, Observaciones a un nuevo proyecto de ley que regula las empresas de beneficio e interés colectivo desde la experiencia comparada, Revista Chilena de Derecho Privado, No. 31, 381-425

Stella Richter M., 2017, Società benefit e società non benefit, Riv. Dir. Comm., 271-285

Thirion E., 2017, Statute for social and solidarity- based enterprises. European Added Value Assessment Accompanying the European Parliament's legislative own-initiative report, available at http://www.europarl.europa.eu/thinktank/en/home.html (last accessed April 2, 2019)

Tombari U., 2019, "Potere” e "interessi” nella grande impresa azionaria, Giuffrè

Tsagas G., 2017), Section 172 of the Companies Act 2006: Desperate Times Call for Soft Law Measures, in Nina Boerger and Charlotte Villiers (eds.), Shaping the Corporate Landscape, Hart Publications, available at https://papers.ssrn.com/sol3/papers.cfm?abstract_id=2996090 (last accessed April 2, 2019)

Unidroit, 2010, Guidelines for a Legal Framework for Social Enterprise, C.D. (89) 7 Add. 5

Wang M., and X. Zhu, 2010, An outline of social enterprises, China Nonprofit Review (Beijing), 6, 1-31 (in Chinese)

Yunus M., 2010, Building Social Business: The New Kind of Capitalism that Serves Humanity's Most Pressing Needs, PublicAffairs

Zeberkiewicz J., 2019, Delaware's Voluntary Sustainability Certification Law, Harvard Law School Forum on Corporate Governance and Financial Regulation (15 July 2019) 
available at https://corpgov.law.harvard.edu/2018/07/15/delawares-voluntarysustainability-certification-law/ (last accessed April 2, 2019) 